\title{
Night Spraying Peanut Fungicides I. Extended Fungicide Residual and Integrated Disease Management
}

\author{
J. Augusto, T. B. Brenneman, and A. K. Culbreath, Department of Plant Pathology, and P. Sumner, Department of \\ Biological and Agricultural Engineering, University of Georgia Coastal Plain Experiment Station, Tifton 31793
}

\begin{abstract}
Augusto, J., Brenneman, T. B., Culbreath, A. K., and Sumner, P. 2010. Night spraying peanut fungicides I. Extended fungicide residual and integrated disease management. Plant Dis. 04:676682.

The efficacy of chemical control of stem rot (caused by Sclerotium rolfsii) of peanut (Arachis hypogaea) relies partially on increasing deposition and residual activity in the lower canopy. Tebuconazole $(0.21 \mathrm{~kg}$ a.i./ha, four applications $)$ and azoxystrobin $(0.31 \mathrm{~kg}$ a.i./ha, two applications) were each applied on peanut plants in daylight or at night, when leaves were folded, in two Tifton, GA, field trials in 2007. Both timings of each fungicide provided similar control of early leaf spot (caused by Cercospora arachidicola). Night applications of azoxystrobin and tebuconazole reduced stem rot at digging and increased yield compared with day applications. Night applications of tebuconazole were also tested in Nicaragua from 2005 to 2007. Peanut plants had less stem rot, similar levels of rust (caused by Puccinia arachidis), and higher yield with night applications than with day applications. Residual activity of azoxystrobin and tebuconazole were improved on the bottom shaded leaves (on which fungicides would be better deposited with night application) compared with top, sun-exposed leaves (where most fungicide would be deposited with a day application) according to a bioassay with $S$. rolfsii. Increased fungicide residual activity within the bottom canopy may increase fungicide efficacy on stem rot and augment peanut yield.
\end{abstract}

Stem rot, caused by Sclerotium rolfsii Sacc., is a very destructive soilborne disease of peanut in Georgia (9). Infection of $S$. rolfsii in peanut is restricted to the lower stems in contact with the soil, as well as pegs, pods, and roots. Colonization of peanut tissues coincides with peg and pod development, when peanut branches spread rapidly across the soil. High temperatures $\left(25\right.$ to $\left.30^{\circ} \mathrm{C}\right)$ and remoistened, dried peanut stems and leaves in the soil favor germination of sclerotia $(5,12,31)$. High soil moisture, dense plant stands, and frequent irrigation promote infection and fungal mycelial spread within and between plants $(12,31,32,35)$. Initial symptoms of the infected plants are wilting of one or more branches but the whole plant may wilt and die within a few weeks of infection. These symptoms are usually accompanied by white fungal mycelium and light to dark-brown sclerotia $(0.3$ to $3.0 \mathrm{~mm})$ on the soil surface and diseased plant tissues (26,32). Average annual reduction in crop value due to the disease between 2005 and 2007 was $6.7 \%$, accounting for $\$ 40.6$ million in control costs and damage in Geor-

Corresponding author: J. Augusto

E-mail: jaugusto@uga.edu

Accepted for publication 22 January 2010.

doi:10.1094/PDIS-94-6-0676

(C) 2010 The American Phytopathological Society gia (22-24). In addition to these losses to stem rot, early leaf spot (Cercospora arachidicola Hori) and late leaf spot (Cercosporidium personatum (Berk. \& M.A. Curtis) Deighton) are endemic and can be very damaging as well (22-24).

Peanut growers rely mostly on intensive fungicide programs to minimize the negative impact of both stem rot and leaf spots on peanut yield (33). These fungicides are usually applied by air or ground over the top of the peanut canopy. The foliage of most commercial peanut cultivars is already dense by the time the first or second spray is applied between 30 and 50 days after planting (DAP). Thorough coverage of the foliage is needed to control foliar pathogens but penetration of the canopy to deposit fungicide on lower stems, pegs, and leaves near the soil surface is required to control stem rot. This goal can be achieved, in part, via the use of irrigation to redistribute fungicide residues on the foliage after application. Woodward (45) demonstrated that an 18 -h period between fungicide application and the irrigation event would achieve a good balance of foliar and soilborne disease control, because irrigating too early after application can compromise control of leaf spots. However, only $55 \%$ of peanut acreage in Georgia receives some irrigation (22-24) and the remaining fields are reliant upon rainfall, which often occurs unpredictably in the summer months. Hence, a fungicide application strategy that produces the greatest amount of fungicide deposition in the lower peanut canopy has the potential of increasing control of stem rot.

Researchers have sought to improve fungicide penetration with various methods. Grichar (19) reported using an Asweep spray boom attachment to open the peanut canopy for better fungicide spray penetration to control stem rot in narrowband applications. In Ontario, Canada, foliar trimming of carrot improved fungicide penetration into the canopy and reduced the number of Sclerotinia sclerotiorum apothecia compared with the nontrimmed treatments (28). Work done by Coyne et al. (13) showed that spraying fungicide to an open rather than closed canopy was more effective for the control of $S$. sclerotium in dry bean. In peanut, stem rot control was increased when benomyl was applied after pruning vines with a rotary mower (2). Studies of fungicide applications following peanut pruning have also been conducted to control Sclerotinia blight (3). Pruned plots and iprodione-sprayed plots did not differ in disease incidence, and pruned plots treated with fungicide had less disease than nonpruned plots treated with the same fungicide (3). In similar studies in fields with high Sclerotinia blight pressure, one pruning event with two fluazinam fungicide applications had 58\% disease reduction compared with no pruning with fluazinam applications (10). The authors suggested that the effect was due to better penetration of fluazinam to infection sites at the soil surface. Pruning effects on yield in these studies $(3,10)$ were variable but, in general, pruning can significantly reduce peanut pod yields $(34,40)$.

An alternative method of improving fungicide penetration in the bottom peanut canopy is night spraying of fungicides. Peanut plants fold their leaves at night (Fig. 1) and open them in the daytime (Fig. 2 ), a process known as nyctinasty (41). As a result of night leaf folding, the otherwise thick canopy becomes sparser to the degree that even the soil surface is often visible. Peanut growers in Nicaragua observed that fungicides applied at night were more effectively reaching the infection court of Sclerotium rolfsii and resulted in improved control of stem rot. In part II of this article series, night application was shown to increase deposition of a nonfungicidal tracer dye in the lower canopy of peanut compared with a day application 
(1). Another possible benefit of night leaf folding in peanut is decreased fungicide photolysis when fungicides are applied at night. At daybreak, peanut foliage unfolds, allowing the increased fungicide residues deposited deeper in the canopy to be shaded. Conversely, a much higher percentage of fungicide applied after daybreak remains on the very top leaves where it is exposed to sunlight and, therefore, a greater potential for photodegradation. The degree of photodegradation will depend on the chemical structure and formulation of each fungicide. Some fungicides such as propiconazole are readily photolyzed in the UV region of the solar spectrum, although propiconazole reacts slowly to solar radiation (42). However, no literature is available for photodegradation of tebuconazole fungicide. Bartlett et al. (4) indicated that photolysis can be an important route of environmental degradation for strobilurin fungicides, and azoxystrobin is photodegraded at a $\lambda=290 \mathrm{~nm}$ (21). Most fungicide photolysis studies have been conducted under laboratory conditions by irradiating with UV light (27) and have used organic solvents with selected functionalities as substitutes for components of plant waxes for photodegradation (30).

The primary objective of this study was to compare night and day fungicide applications for the control of stem rot and leaf diseases and to quantify the benefits of improved disease control on peanut pod yield. The second objective was to evaluate the effect of direct sun on the upper canopy (where most fungicide would be deposited with a day application) and shade on the bottom canopy (where more fungicide would be deposited with night application) on the residual activity of equivalent azoxystrobin and tebuconazole fungicide deposits using a bioassay procedure with $S$. rolfsii (46). The final objective was to compare and quantify solar radiation and leaf temperature of sun-exposed and shaded peanut leaves.

\section{MATERIALS AND METHODS}

Fungicide application timings in Tifton, GA. Two field experiments were conducted at the University of Georgia Tifton Campus Blackshank (latitude: N31 ${ }^{\circ}$ $30.066^{\prime}$ and longitude: W083 ${ }^{\circ} 32.801^{\prime}$ ) and Lang (latitude: $\mathrm{N} 31^{\circ} 30.642^{\prime}$ and longitude: W083 $32.841^{\prime}$ ) Farms in 2007 to evaluate night and day fungicide applications for the control of stem rot, leaf spots, and peanut pod yield. The soil type in both locations was a Tifton loamy sand, 2 to $5 \%$ slope, with a pH of 6.0 (15). The fields were bottom plowed to a depth of 20 to 25 $\mathrm{cm}$, disk harrowed, and marked off in beds $1.83 \mathrm{~m}$ wide. The preemergence herbicides ethalfluralin (Sonalan; Dow AgroSciences, Indianapolis, IN) at $0.72 \mathrm{~kg}$ a.i./ha and smetolachlor (Dual Magnum; Syngenta Crop Protection, Inc., Greensboro, NC) at $1.5 \mathrm{~kg}$ a.i./ha were applied and incorpo- rated within the upper $5 \mathrm{~cm}$ of soil with a rototiller a week before peanut was planted. The fields had been under continuous peanut cultivation for at least 5 years, with a history of epidemics caused by $S$. rolfsii. The cv. Georgia Green (6) was planted with a two-row Monosem planter at 23 seeds/m on 11 May at Blackshank and 16 May at Lang Farm. Aldicarb (Temik 15G; Bayer CropScience, Research Triangle Park, NC) was applied in furrow (0.67 kg a.i./ha) and on a $0.3-\mathrm{m}$ band (1.68 $\mathrm{kg}$ a.i./ha) at planting for the control of thrips and nematodes, respectively. The postemergence herbicide imazapic (Cadre 70 DG; BASF Corp., Research Triangle Park, NC) at $0.07 \mathrm{~kg}$ a.i./ha was applied 40 to 45 DAP. Gypsum $(1,120 \mathrm{~kg} / \mathrm{ha})$ was applied at the early pegging stage (30 to 40 DAP) to provide additional calcium in the soil.

The experimental design was a randomized complete block and treatments were replicated six times at each of the two locations. Each plot was a two-row bed, $7.62 \mathrm{~m}$ long, and row spacing was $0.91 \mathrm{~m}$.

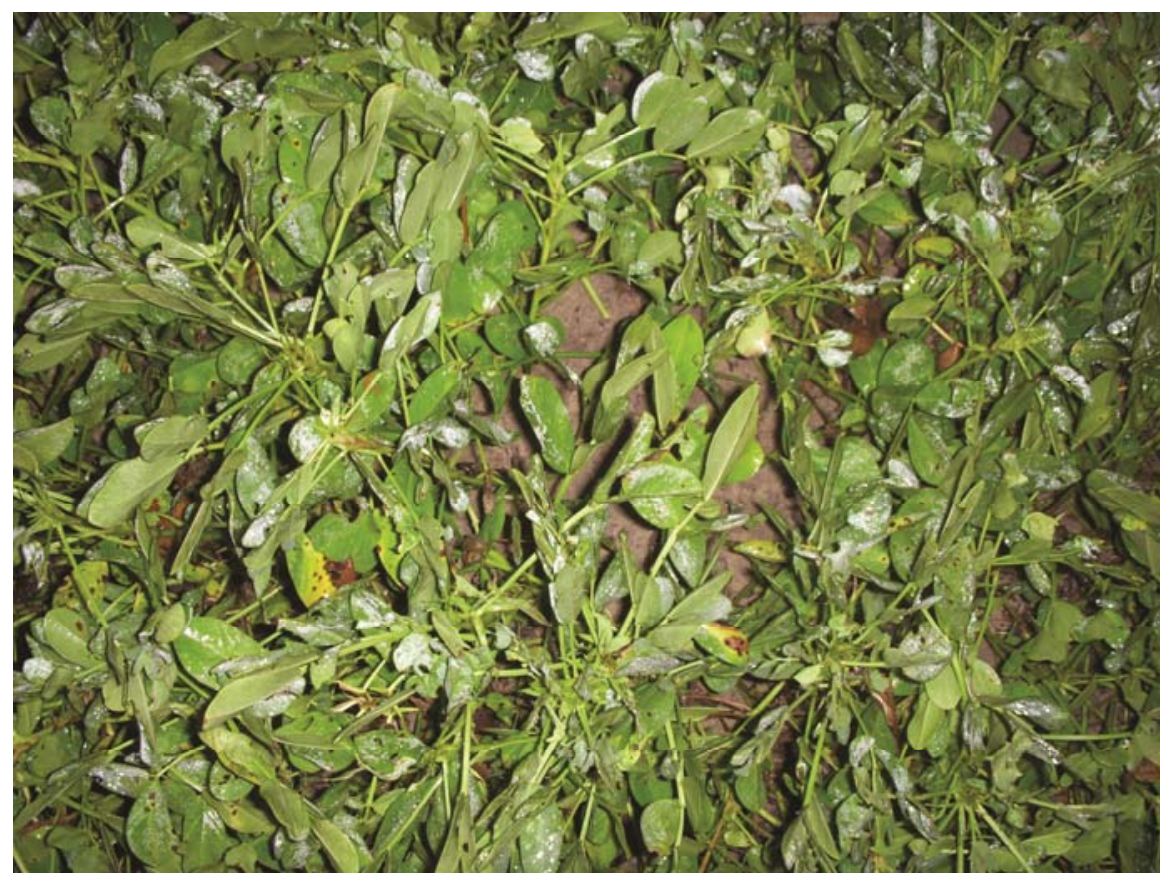

Fig. 1. Canopy of peanut cv. Georgia Green at night (about 4:00 A.M.). Picture was taken 120 days after planting in Tifton, GA. Note the sparse canopy due to the folded leaves.

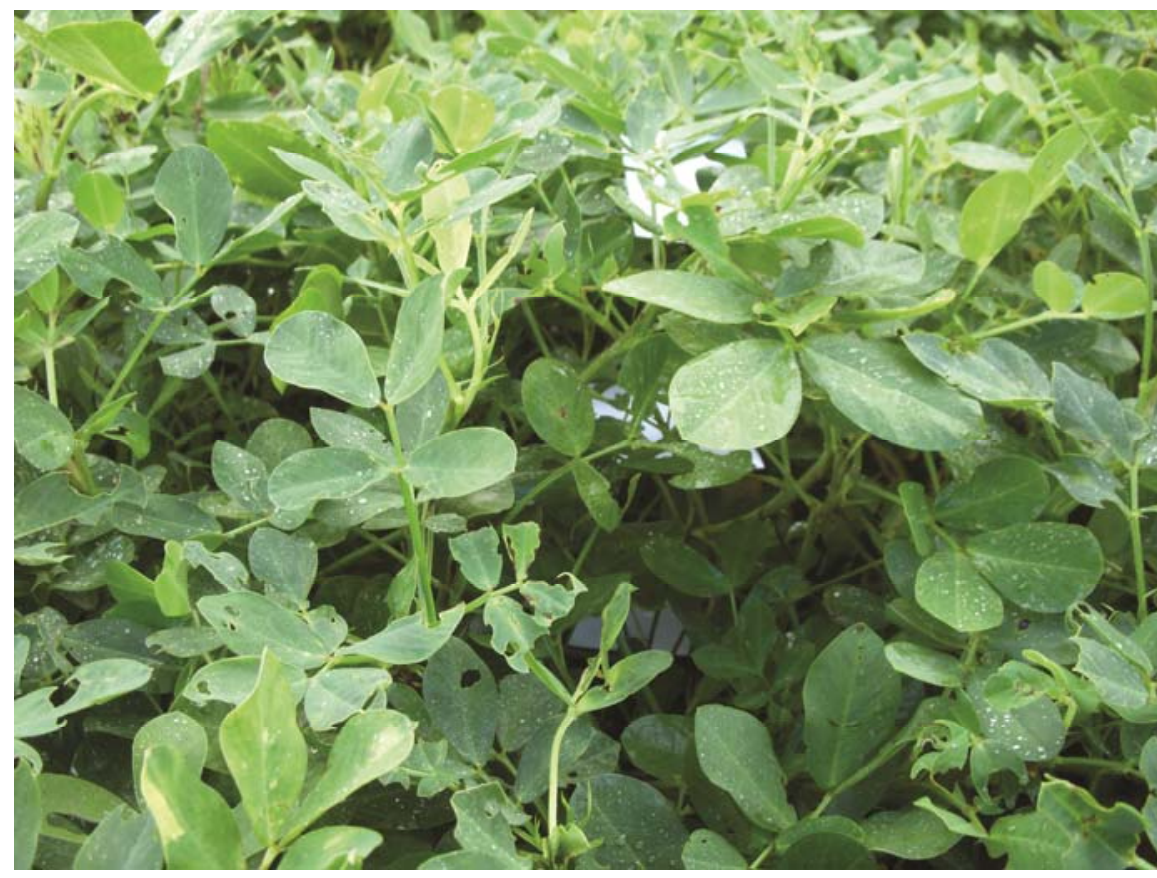

Fig. 2. Same peanut field as in Figure 1, the picture taken on the same day but during daylight (about 10:00 A.M.). Note the dense canopy due to the unfolded and overlapping leaves. 
The blocks (replications) were separated by $2.4-\mathrm{m}$ fallow alleys. Seven spray programs were evaluated, and either azoxystrobin (Abound F; Syngenta Crop Protection, Inc.) or tebuconazole (Folicur 3.6 F; Bayer CropScience) were used for the control of stem rot (Table 1). According to standard use recommendations for growers (25), azoxystrobin (0.31 kg a.i./ha) was applied twice during the season while tebuconazole $(0.21 \mathrm{~kg}$ a.i./ha) was applied as a midseason four-spray block. Both fungicides were applied either at night (3:00 A.M. to 5:00 A.M.), when leaves were folded, or during the day (10:00 A.M. to 12:00 P.M.), on the same day when leaves were unfolded. There was a treated control with application of the protectant fungicide chlorothalonil (1.26 kg a.i./ha, Bravo WeatherStik; Syngenta Crop Protection Inc.) to prevent defoliation by leaf spots (8). Chlorothalonil has no activity on stem rot $(9,14)$, and it was also used on the remaining applications of each of the above programs to give a complete seven-spray program for each treatment. Fungicide applications for all spray program treatments were initiated 30 to $40 \mathrm{DAP}$, and subsequent applications followed a 14-day schedule for a total of seven applications (Table 1). One treatment of each night fungicide treatment also received a fullseason program of chlorothalonil applications. This was to insure adequate leaf spot control and foliage retention in case the night applications were not effective on leaf spot pathogens. Applications 1, 2, and 7 were day cover sprays of all plots, with chlorothalonil applied with a conventional tractor-mounted sprayer at about $345 \mathrm{kPa}$ using three $\mathrm{D}_{2-13}$ nozzles per row. Applications 3 to 6 for all treatments were applied with a $\mathrm{CO}_{2}$-pressurized beltpack sprayer using a 2-liter bottle and a broadcast boom set up to apply 187 liters/ha at $276 \mathrm{kPa}$ traveling $4 \mathrm{~km} / \mathrm{h}$. The sprayer was equipped with three Conejet TX-SS6 hollow cone nozzles (Spraying Systems Co., Wheaton, IL) per row positioned 0.3 to 0.5 $\mathrm{m}$ above the top peanut canopy. Peanut in the two locations received sprinkler irrigation as needed to prevent moisture stress but water was intentionally not applied for several days following the spray applications to avoid redistribution of fungicide.

Fungicide application timings in Nicaragua. Three field experiments were established across three locations at La Esperanza (latitude: N12 ${ }^{\circ} 29.813^{\prime}$ and longitude: W086 ${ }^{\circ} 54.393^{\prime}$ ) and San Jose de Telica (latitude: N12 ${ }^{\circ} 30.739^{\prime}$ and longitude: $\mathrm{W}^{\circ} 86^{\circ}$ 51.017') Farms (Leon) and Cocal (latitude: $\mathrm{N} 12^{\circ} 38.550^{\prime}$ and longitude: W087 ${ }^{\circ}$ 06.039') Farm (Chinandega) during the 2005 to 2007 growing seasons. The experiments were in a randomized complete block design and treatments were replicated five times at each location to evaluate night and day applications of tebuconazole on disease control and peanut pod yield. Georgia Green cv. was planted at 28 seeds/m each year. In 2005 and 2006, plots consisted of 12 beds (with two rows each bed), each $10 \mathrm{~m}$ long, and rows were spaced $0.91 \mathrm{~m}$ apart. In 2007, each plot was $10 \mathrm{~m}$ long and had four beds with row spacing of $0.91 \mathrm{~m}$. The replications were separated by 4-m fallow alleys. Treatments were a nonsprayed control and tebuconazole $(0.21 \mathrm{~kg}$ a.i./ha) and chlorothalonil (0.96 kg a.i./ha) applied either at night (9:00 P.M. to 10:00 P.M.) or after daybreak (10:00 A.M. to 12:00 P.M.) as midseason four-spray blocks (sprays 3 to $6)$. Sprays 1, 2, and 7 were cover sprays of chlorothalonil. The fungicides were applied with a tractor-mounted sprayer as described previously. All plots were established and maintained uniformly, with the exception of experimental treatments.
Leaf spot assessment. Leaf spot, primarily early leaf spot, was evaluated using the Florida 1-to-10 intensity scale, where $1=$ no disease $(0 \%$ defoliation $) ; 2=$ very few lesions and none on upper canopy ( $0 \%$ defoliation); 3 = few lesions and very few on upper canopy ( $0 \%$ defoliation); $4=$ some lesions, with more on upper canopy and noticeable defoliation (5\%); $5=1 \mathrm{l}$ sions noticeable even on upper canopy and noticeable defoliation (20\%), $6=$ lesions numerous and very evident on upper canopy, with significant defoliation (50\%), $7=$ lesions numerous on upper canopy, with much defoliation (75\%); $8=$ upper canopy covered with lesions, with high defoliation (90\%); 9 = very few leaves remaining and those covered with lesions, some plants completely defoliated (98\%); and $10=$ plants completely defoliated or dead (11). Leaf spot estimate of a plot was an arithmetic mean of the individual visual assessment values of all plants in that plot. In Tifton, ratings of leaf spots were taken at 95 DAP and subsequent ratings were at 7 day intervals in both locations but, in Nicaragua, the intensity of leaf spot was low and not recorded.

Peanut rust assessment. In Nicaragua, peanut rust (caused by Puccinia arachidis) was rated about 110 DAP each year using the ICRISAT 1-to-9 severity rating scale, where $1=$ no disease; 2 = few necrotic spots on older leaves; $3=$ few pustules, mainly on older leaves; $4=$ pustules mostly on lower and middle leaves and disease evident; 5 = many pustules, mostly on lower and middle leaves, with yellowing and necrosis of lower and middle leaves; $6=$ as for rating 5 , but heavy sporulation in pustules; $7=$ pustules all over plant, with lower and middle leaves withering; $8=$ as for rating 7 , except withering is more severe; and $9=50$ to $100 \%$ of leaves withered (39). Peanut rust estimate

Table 1. Effect of night and day fungicide sprays on leaf spot, stem rot incidence, and peanut pod yield across two locations (Blackshank and Lang Farms, Tifton, GA) during the 2007 growing season ${ }^{\mathrm{w}}$

\begin{tabular}{|c|c|c|c|c|c|c|c|c|c|c|}
\hline \multirow[b]{2}{*}{ Fungicide application timing ${ }^{\mathrm{z}}$} & \multirow[b]{2}{*}{ Application no. } & \multicolumn{4}{|c|}{ Leaf spot rating $(\text { DAP })^{x}$} & \multicolumn{4}{|c|}{ Stem rot incidence $(\mathrm{DAP})^{\mathrm{y}}$} & \multirow[b]{2}{*}{ Yield (kg/ha) } \\
\hline & & 95 & 102 & 109 & 116 & 102 & 109 & 116 & 135 & \\
\hline $\begin{array}{l}\text { Chlorothalonil day } \\
\text { Azoxystrobin day }\end{array}$ & $\begin{array}{c}1,2,4,6,7 \\
3,5\end{array}$ & $2.7 \mathrm{~b}$ & $2.7 \mathrm{bc}$ & $2.7 \mathrm{bc}$ & $3.1 \mathrm{~b}$ & $4.5 \mathrm{~b}$ & $10.3 \mathrm{~b}$ & $15.5 \mathrm{bc}$ & $23.3 \mathrm{~b}$ & $2,517.2 \mathrm{bc}$ \\
\hline $\begin{array}{l}\text { Chlorothalonil day } \\
\text { Azoxystrobin night }\end{array}$ & $\begin{array}{c}1,2,4,6,7 \\
3,5\end{array}$ & $2.6 \mathrm{~b}$ & $2.6 \mathrm{c}$ & $2.7 \mathrm{bc}$ & $3.2 \mathrm{~b}$ & $4.5 \mathrm{~b}$ & $6.2 \mathrm{~b}$ & $6.2 \mathrm{~d}$ & $6.3 \mathrm{c}$ & $4,269.5 \mathrm{a}$ \\
\hline $\begin{array}{l}\text { Chlorothalonil day } \\
\text { Azoxystrobin night }\end{array}$ & $\begin{array}{l}1-7 \\
3,5\end{array}$ & $2.6 \mathrm{~b}$ & $2.6 \mathrm{c}$ & $2.7 \mathrm{bc}$ & $3.1 \mathrm{~b}$ & $1.3 \mathrm{~b}$ & $4.5 \mathrm{~b}$ & $5.3 \mathrm{~d}$ & $5.3 \mathrm{c}$ & $4,241.0 \mathrm{a}$ \\
\hline $\begin{array}{l}\text { Chlorothalonil day } \\
\text { Tebuconazole day }\end{array}$ & $\begin{array}{c}1,2,7 \\
3-6\end{array}$ & $2.8 \mathrm{ab}$ & $2.8 \mathrm{ab}$ & $2.9 \mathrm{ab}$ & $3.9 \mathrm{a}$ & $7.5 \mathrm{~b}$ & $12.8 \mathrm{~b}$ & $17.7 \mathrm{~b}$ & $26.5 \mathrm{~b}$ & $2,968.9 \mathrm{~b}$ \\
\hline $\begin{array}{l}\text { Chlorothalonil day } \\
\text { Tebuconazole night }\end{array}$ & $\begin{array}{l}1,2,7 \\
3-6\end{array}$ & $2.6 \mathrm{~b}$ & $2.7 \mathrm{bc}$ & $2.8 \mathrm{abc}$ & $4.1 \mathrm{a}$ & $5.7 \mathrm{~b}$ & $7.8 \mathrm{~b}$ & $8.8 \mathrm{~cd}$ & $13.0 \mathrm{c}$ & $3,912.5 \mathrm{a}$ \\
\hline $\begin{array}{l}\text { Chlorothalonil day } \\
\text { Tebuconazole night }\end{array}$ & $\begin{array}{l}1-7 \\
3-6\end{array}$ & $2.7 \mathrm{~b}$ & $2.7 \mathrm{bc}$ & $2.8 \mathrm{abc}$ & $3.3 \mathrm{~b}$ & $4.7 \mathrm{~b}$ & $6.7 \mathrm{~b}$ & $7.0 \mathrm{~cd}$ & $9.3 \mathrm{c}$ & $4,207.1 \mathrm{a}$ \\
\hline Chlorothalonil day & $1-7$ & $2.9 \mathrm{a}$ & $3.0 \mathrm{a}$ & $3.0 \mathrm{a}$ & $4.1 \mathrm{a}$ & $28.3 \mathrm{a}$ & $41.7 \mathrm{a}$ & $50.8 \mathrm{a}$ & $58.0 \mathrm{a}$ & $2,467.8 \mathrm{c}$ \\
\hline
\end{tabular}

${ }^{\mathrm{w}}$ Numbers in a column followed by the same letters are not statistically different according to Fisher's protected least significant difference $(P=0.05)$.

${ }^{\mathrm{x}}$ Leaf spot, primarily early leaf spot, rating based on Florida 1 -to- 10 rating scale, where $1=$ no disease and $10=$ dead plant. $\mathrm{DAP}=$ days after planting.

${ }^{y}$ Stem rot incidence in each plot was based on the percentage of 30-cm row sections containing one or more consecutive plants with signs or symptoms of infection with Sclerotium rolfsii. DAP = days after planting; $135 \mathrm{DAP}=$ digging.

${ }^{\mathrm{z}}$ Chlorothalonil, azoxystrobin, or tebuconazole followed by night or day indicates that the corresponding fungicide was applied at night (3:00 A.M. to 5:00 A.M.) on plants with folded leaves or during the day (10:00 A.M. to 12:00 P.M.) on plants with unfolded leaves. 
of a plot was an arithmetic mean of the individual visual assessment values of all plants in that plot. Peanut rust was not present in plots in Tifton.

The leaf spot intensity and peanut rust severity in these rating scales are discrete variables at the level of the individual plant; however, at the plot level, as a result of the averaging process of all plants, they are (pseudo-)continuous variables (29).

Stem rot assessment. Number of disease foci caused by $S$. rolfsii was assessed at 102, 109, and 116 DAP and 1 day after digging and inverting (130 to 140 DAP) for each plot. Stem rot focus consisted of one or more consecutive affected plants in a 30-cm section of row. Distinctive symptoms and signs of $S$. rolfsii included wilted and dead stems or entire plants, often with whitish fungal mycelium and light to darkbrown sclerotia on the plant tissues near or on the soil surface. Percent stem rot for each plot was determined as $\%$ stem rot $=$ [(no. of $30-\mathrm{cm}$ sections affected)/(no. of $30-\mathrm{cm}$ total sections in the plot) $] \times 100$.

Pod yield assessment. All plots were mechanically dug and inverted between 130 to 140 DAP with a KMC digger/inverter but the hull-scrape method of estimating pod maturity (44) was used to determine the optimum digging date. Windrows were mechanically harvested with a two-row combine approximately 5 days later. The final pod moisture content after air-drying was about 9\% (wt/wt). Weight of pods was recorded after soil and foreign materials were removed from the plot samples.

Statistical analysis for fungicide application timings in Georgia and Nicaragua. Disease assessments and pod yield were subject to analysis of variance using the mixed procedure of SAS (version 9.1; SAS Institute, Cary, NC) to determine significant differences $(P \leq 0.05)$ among treatments in Tifton and Nicaragua, respectively. Analysis of variance for leaf spot, peanut rust, stem rot, and pod yield was performed with data arranged in a complete block design nested within locations for the Tifton and Nicaragua experiments. Year-location-treatment, year-treatment, and location-treatment interactions for the variables were used to assess whether data could be combined across locations and years. The least significant difference $(P=$ 0.05 ) was then calculated for mean separations for significant treatments in both Tifton and Nicaragua locations.

Fungicide photolysis and environmental data. Two field experiments were conducted in 2008, each a repeatedmeasures design with treatments replicated six times at Blackshank (latitude: $\mathrm{N} 31^{\circ}$ 30.104' longitude: $\mathrm{W}^{\prime} 083^{\circ} 32.815^{\prime}$ ) and Lang (latitude: $\mathrm{N} 31^{\circ} 30.636^{\prime}$ longitude: W083 $^{\circ} 32.911^{\prime}$ ) Farms, Tifton, GA to compare fungicide residual activity on directly sun-exposed foliage (where most fungicide would be deposited with a day application) and on bottom, shaded leaves (where fungicides would be better deposited with night application). Cv. Georgia Green was planted on 9 and 16 May at Blackshank and Lang Farms, respectively. All management practices were as described above for the Tifton experiments but no fungicides were applied except for the azoxystrobin and tebuconazole treatments. Grouping factor was sun exposure (shaded and sun-exposed leaves). The shaded leaves were from the main stem that was pinned to the soil and, thus, shaded by the peanut canopy. Fungicide treatments were single applications of (i) azoxystrobin at $0.31 \mathrm{~kg}$ a.i./ha, (ii) tebuconazole at $0.21 \mathrm{~kg}$ a.i./ha, or (iii) water as a control. The repeated measures were sampling dates after fungicide treatments at (i) 0 , (ii) 7, (iii) 14 , and (iv) 21 days. The top three fully expanded peanut leaves from the main stem of nine arbitrarily selected peanut plants per plot were dipped into a fungicide suspension or water for 5 $\mathrm{s}$, then allowed to dry to the touch. The main stems of the plants marked as sun exposed were left exposed to direct sunlight whereas main stems from plants marked as shaded were carefully bent into the bottom canopy and pinned close to the soil with a U-shaped wire for the duration of the experiment. Fungicide treatments were made on 10 August, approximately 90 DAP, when the canopy was dense and when fungicide applications to control stem rot were critical. At day 0, leaves of both shaded and sun-exposed treatments, dipped for $5 \mathrm{~s}$ into fungicide suspension or water, were left to dry for approximately $30 \mathrm{~min}$ before they were collected for bioassay with $S$. rolfsii. Subsequent sampling dates were at 7, 14, and 21 days following fungicide and water treatments. Twentyfour leaflet samples (four leaflets per rep) from each treatment and location were placed in resealable plastic bags in the field, transported to the laboratory in a cooler, and inoculated the same day with 4-mm-diameter potato dextrose agar mycelial plugs from the periphery of 3-day-old actively growing colonies of $S$. rolfsii (isolate SR-18, originally isolated from peanut). A mycelial plug was aseptically placed with the mycelium down on the middle of each leaflet on moistened Whatman no. 2 filter paper inside a petri dish. Inoculated leaves were kept for 7 days at room temperature $\left(25\right.$ to $\left.28^{\circ} \mathrm{C}\right)$ and the percent inhibition of necrotic leaf area (\%NLAI), indicative of fungicide residual activity, was then calculated following visual estimate of percent necrotic leaf area as follows: \%NLAI $=[(\%$ NLAWC $\%$ NLAFT $) /(\%$ NLAWC $)] \times 100$, where $\%$ NLAWC and \%NLAFT were percent necrotic leaf area with water control and percent necrotic leaf area with fungicide treatment, respectively. The percent necrotic leaf area was always visually estimated by the same rater to ensure reproducibility.
At the time of fungicide applications for the photolysis study, leaf temperatures were measured using a hand-held infrared thermometer (Cole-Parmer Instrument Co., Vernon Hills, IL) with a small, circular sensing element aimed at the leaf surface. The infrared thermometer was positioned no more than $20 \mathrm{~cm}$ between the sensing element and the laser-sighted leaf surface because the field of view of the thermometer widens with increasing distance. The solar radiation was recorded with a GE Type 214 Light Meter (Lamp Marketing Department, Nela Park Cleveland, $\mathrm{OH}$ ) positioned within the canopy. Leaf temperatures and solar radiation were recorded at the top (sun-exposed leaves) and bottom (shaded leaves) of the canopies at 90 DAP, when the peanut plants were about $28 \mathrm{~cm}$ tall. Four readings were recorded for both solar radiation and temperature in each canopy layer in each plot during the hottest part of the day in early afternoon with full sun.

Statistical analysis of repeatedmeasures fungicide photolysis test and environmental data. Fungicide photolysis tests were computed using the mixed procedure of SAS (version 9.1 statistical software) to first model the covariance structure. Covariance structure of the data was defined by invoking the RANDOM or REPEATED statements. Three candidate covariance models-specifically, compound symmetry (cs), unstructured (un), and Toeplitz (toep)-were fitted for the model that minimized Akaike Information Criterion (AIC), AIC Corrected (AICC), and Bayesian Information Criterion (BIC). The models were compared by varying the RANDOM (toep) and REPEATED (cs, un, and toep) statements to obtain the AIC, AICC, and BIC in the mixed procedure. The REPEATED statement included cs, un, or toep for "type" option and sunexposure (by fungicide) effects for "subject" option for all the three models. In addition to the REPEATED statement, the Toeplitz model had RANDOM statement with sun-exposure (by fungicide) effects. The MODEL statement included fungicide, sampling date, and fungicidesampling date interaction. The unstructured model was chosen for further data analysis because it had the lowest AIC, AICC, and BIC and provided the best fit for data analysis compared with other covariance models. The treatments and sampling date effects were then assessed using the generalized least-squares means. Data on irradiation and temperature of foliage between top and bottom peanut canopy layers were analyzed by paired (samples) $t$ test using the $t$ test procedure of SAS.

\section{RESULTS}

Fungicide application timings in Tifton, GA. Analysis of variance for leaf spot, stem rot, and pod yield indicated no significant location-treatment interactions. 
The interaction application timingfungicide was significant for stem rot at 116 DAP $(P=0.018)$, digging $(P=0.009)$, and yield $(P=0.026)$. Thus, data were combined across locations (Table 1). Leaf spot severity in the 2007 trials was moderate. Tebuconazole fungicide was less effective for the control of leaf spots than azoxystrobin, regardless of application timing. Night and day applications of azoxystrobin or tebuconazole had similar leaf spot ratings throughout the season. Azoxystrobin and tebuconazole applied at night or during the day provided similar stem rot con-
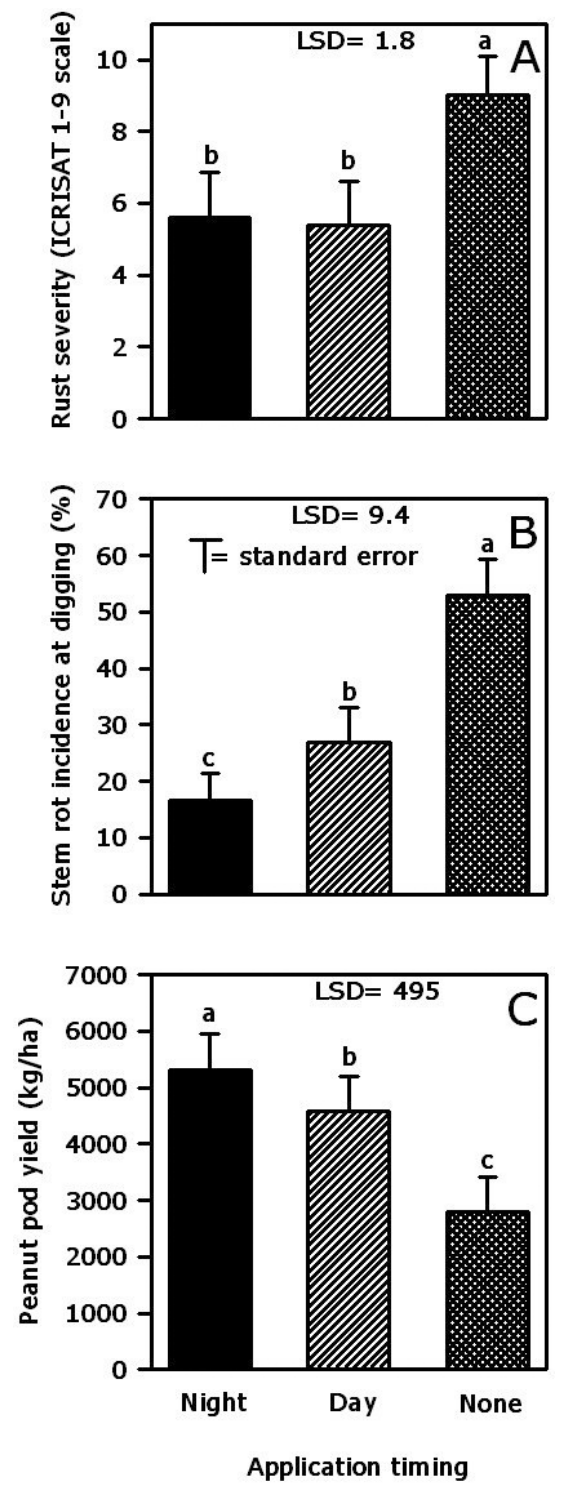

Fig. 3. Effect of application timings of tebuconazole fungicide on $\mathbf{A}$, peanut rust severity; $\mathbf{B}$, stem rot incidence at digging; and $\mathbf{C}$, peanut pod yield across three locations in Nicaragua during the 2005 to 2007 seasons. Tebuconazole was applied at night between 9:00 and 10:00 P.M., when leaves were folded, and during daylight between 10:00 A.M. and 12:00 P.M., when leaves were unfolded. Application timing bar heights with different letters for peanut rust severity, stem rot incidence, or peanut pod yield are significantly different according to least significant difference (LSD, $P=0.05$ ). trol but both fungicides and application timings decreased stem rot incidence compared with the chlorothalonil control plots at 102 and 109 DAP (Table 1). At 116 DAP, night applications of azoxystrobin or tebuconazole decreased stem rot compared with day applications of the same fungicides. Nevertheless, day applications of both fungicides were more effective in decreasing stem rot than the chlorothalonil control. At digging, stem rot incidence was high in plots sprayed with chlorothalonil alone, and night applications of azoxystrobin and tebuconazole reduced stem rot incidence by 73 and $51 \%$, respectively, compared with the day applications of the same fungicides. Day application of azoxystrobin or tebuconazole decreased stem rot at digging compared with the chlorothalonil control plots but azoxystrobin did not significantly $(P=0.093)$ increase pod yields. Night applications of azoxystrobin and tebuconazole increased pod yield by $1,752 \mathrm{~kg} / \mathrm{ha}$ and $944 \mathrm{~kg} / \mathrm{ha}$, respectively, compared with similar day application treatments.

Fungicide application timings in Nicaragua. The analysis of variance showed neither a significant three-way interaction of year-location-treatment nor significant two-way interactions of yeartreatment or location-treatment. However, the partial effects of the treatments were significant $(P=0.034)$. Data were combined across years and locations for final analysis of variance for peanut rust, stem rot, and pod yield. Night and day applications of tebuconazole provided similar control of peanut rust (Fig. 3A) but night applications reduced stem rot by $63 \%$ (Fig. $3 \mathrm{~B})$ and increased peanut pod yield by $7 \%$ (Fig. 3C) compared with the day application of the same fungicide. Both night and day application of tebuconazole decreased peanut rust and stem rot and increased

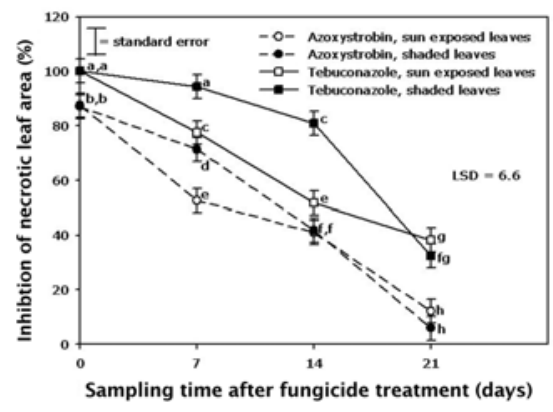

Fig. 4. Effect of sun exposure at Lang and Blackshank Farms, Tifton, GA in 2008 on fungicide residual activity on peanut as measured by a leaf inoculation bioassay. Percent inhibition of necrotic leaf area, indicative of fungicide residual activity, for the sun-exposed and shaded leaves treated with fungicides was determined as percent necrotic leaf area reduction to the (sun-exposed) water-control leaves. Treatment points (in circles and squares) with different letters are significantly different in percent inhibition of necrotic leaf area according to least significant difference (LSD, $P=0.05$ ). peanut yield compared with nonsprayed control plots.

Fungicide photolysis and environmental data. No significant interaction was found in fungicide photolysis between location and treatments but there was significant $(P=0.027)$ interaction between treatments and sampling dates for inhibition of necrotic leaf area. Thus, data were pooled across locations. At day 0, percent necrotic leaf area of the control (watertreated) leaflets was similar for the shaded and sun-exposed leaflets (68\% average). However, for the subsequent samplings at 7,14 , or 21 days after treatment, control leaflets from shaded leaves had significantly more necrotic leaf area than control leaflets from sun-exposed leaves. Therefore, percent necrotic leaf area with water control from sun-exposed leaves $(68,88$, 86 , and $89 \%$ for sampling day $0,7,14$, and 21 , respectively) was used to calculate the percent inhibition of necrotic leaf area of both shaded and sun-exposed fungicide treated leaves, and results of inhibition of necrotic leaf area are scaled as percentage of the control from sun-exposed leaves.

At day 0, azoxystrobin and tebuconazole inhibited the development of necrotic area in the bioassayed leaves by 87 and $100 \%$, respectively (Fig. 4). Sun-exposed and shaded leaves had similar inhibition of necrotic leaf area for both fungicides. The inhibition of necrotic leaf area from $S$. rolfsii colonization decreased over the next 21 days, and tebuconazole consistently provided higher inhibition than azoxystrobin. Both fungicides provided higher inhibition of necrotic leaf area when leaves were shaded compared with the sunexposed leaves but the effect was more pronounced with tebuconazole than azoxystrobin. Differences in inhibition of necrotic leaf area between shaded and sunexposed leaves extended for 7 days for azoxystrobin and 14 days for tebuconazole fungicide (Fig. 4).

The solar radiation tests across locations showed a 10-fold higher light intensity on foliage from the top canopy layer in full sun exposure than leaves from the bottom canopy. However, leaves in the bottom canopy were $2^{\circ} \mathrm{C}$ warmer than those from the top canopy (Fig. 5).

\section{DISCUSSION}

One of the secondary effects of applying fungicides at night when peanut leaves are folded is that deposition on the abaxial leaf surface is increased relative to deposition on the adaxial side. This is readily apparent when fungicides such as chlorothalonil that leave a visible residue on the leaves are applied. Infection and sporulation of Cercospora arachidicola, the predominant leaf spot pathogen in Georgia in recent years (16), occur on the upper leaf surface (36). The two fungicides applied in this study have significant systemic activity $(4,7)$, which may have compensated for the 
limited spray coverage on the upper leaf surface with night applications. Plots receiving tebuconazole that was not mixed with chlorothalonil had higher leaf spot intensity for both night and day applications than the other treatments; however, this was likely due to the presence of leaf spot isolates with resistance to triazole fungicides which have been documented from this location $(17,37,38)$. Previously, tebuconazole has been effective for controlling peanut leaf spot whether applied full season (seven times) or alternated with chlorothalonil, even at lower rates (8).

In Nicaragua, some growers currently use night applications of tebuconazole to improve control of stem rot but they often apply an additional spray of chlorothalonil during the day to insure control of foliar diseases. In these trials, night applications of tebuconazole improved stem rot control and increased pod yields. In addition, night and day applications of tebuconazole had similar control of $P$. arachidis in Nicaragua and similar levels of leaf spot control in Georgia. Other trials have shown that chlorothalonil, a protectant fungicide with no systemic activity, will provide similar levels of leaf spot control when applied during the day or in the evening when leaves are folded and dry; however, control will be reduced when applied in the early morning on folded, wet leaves (1).

In Georgia trials, improved stem rot efficacy and pod yield increase with night fungicide applications compared with day applications of the same fungicide were more pronounced with azoxystrobin than tebuconazole. The reason for better results with azoxystrobin applied at night is not known but both fungicides have been shown to be effective against stem rot $(9,20)$ and are recommended for use in application regimes to control soilborne peanut diseases in Georgia (25). Applications of azoxystrobin during the day produced pod yields that were similar to those

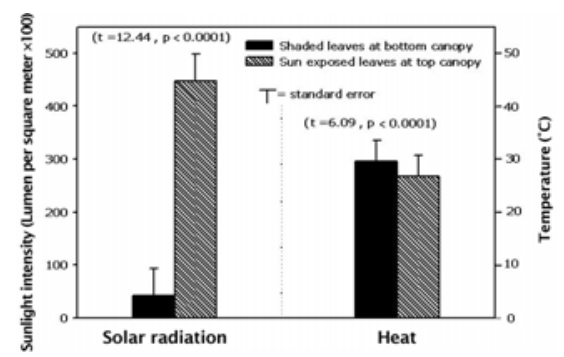

Fig. 5. Effect of shading on levels of solar radiation reaching peanut leaves and leaf temperatures at Blackshank and Lang Farms, Tifton, GA, in 2008. Solar radiation was recorded with a GE Type 214 Lighter Meter positioned within the top and bottom canopies. Leaf temperatures on sun-exposed and shaded leaves were measured using a hand-held infrared thermometer with a circular sensing element aimed at leaf surface and positioned with no more than $20 \mathrm{~cm}$ between the sensing element and the lasersighted leaf surface. from plots receiving only chlorothalonil, which has no activity on stem rot $(9,14)$. This was not expected because day applications of azoxystrobin usually result in higher yields than chlorothalonil alone (20); however, the authors have seen cases where azoxystrobin and other fungicides have had reduced efficacy on soilborne pathogens. The results presented here suggest that at least some of those cases may have been due to poor spray penetration of the canopy and, therefore, reduced deposition of fungicide on the tissues at or near the soil surface.

The impact of light exposure on fungicide degradation was indirectly assessed by inoculating leaves with $S$. rolfsii after those leaves had been treated with fungicides and exposed to direct sunlight or shaded in the bottom canopy. Initial differences between azoxystrobin and tebuconazole on inhibition of necrotic leaf area were possibly due to uneven coverage of azoxystrobin on the leaf surface when dipping the foliage into the fungicide suspension. Commercial formulations of each fungicide were used which contain adjuvants but the azoxystrobin suspension did not wet the leaf as uniformly as did the tebuconazole (our personal observation). Otherwise, both azoxystrobin and tebuconazole are effective against stem rot (caused by $S$. rolfsii) in peanut field plots $(9,20)$. The sun-exposed leaves had lower fungicide residual activity for both products compared with the shaded leaves, presumably due to photodegradation.

The differences in leaf temperatures between the top sun-exposed canopy and the bottom shaded canopy may reflect differences in transpiration rates between top and bottom canopies (43). Air circulation, which provides a cooling effect, is usually low in the bottom canopy. Therefore, leaves within the bottom canopy can be expected to be warmer than those on the top of the canopy. In contrast, the foliage within the top canopy layer is directly exposed to sunlight and has high air circulation, which may result in high transpiration rates and consequent lower leaf temperatures due to the cooling effect. Deshpande et al. (18) found that leaf temperature within a dense canopy was always higher than within an open canopy, and the magnitude of the difference ranged from 0 to $1.5^{\circ} \mathrm{C}$. Differences of this magnitude should have little impact on fungicide degradation.

It is possible that other factors such as exposure to wash off from rain or irrigation would have been greater in the top of the canopy than in the bottom but the systemic nature of both fungicides should have minimized the impact of wash off. Although we cannot describe with certainty the mechanism by which it occurs, clearly, fungicides in the lower canopy do protect the plant for a longer period of time. It is also clear that applying fungi- cides at night can improve their efficacy on peanut stem rot and increase pod yield. This was most evident under severe disease pressure but offers potential for more consistent control and possibly use of lower fungicide rates or fewer applications with low or moderate disease levels. Even if current rates of fungicide are still used, the availability of these benefits with no additional cost to the grower makes this a very attractive concept. The exact percentage of growers applying fungicides at night is not known but a significant number have implemented at least some night applications. Many have done so with conventional spray equipment, and the expanding use of GPS technology should make this even easier to do in the future.

\section{ACKNOWLEDGMENTS}

Funding for the research in Tifton was provided in part by Georgia Peanut Commission. In Nicaragua, funding was provided by the Association of Peanut Growers of that country, and work there was supervised by D. Jerez, M. Hurtado, and R. Saborio. We thank P. Hilton, L. Mullis, R. Griffin, and A. Graham for their assistance.

\section{LITERATURE CITED}

1. Augusto, J., Brenneman, T. B., Culbreath, A K., and Sumner, P. 2010. Night spraying peanut fungicides II. Application timings and spray deposition in the lower canopy. Submitted to Plant Dis. 94:000-000.

2. Backman, P. A., Rodriguez-Kabana, R., and Williams, J. C. 1975. The effect of peanut leaf spot fungicides on the nontarget pathogen, Sclerotium rolfsii. Phytopathology 65:773-776.

3. Bailey, J. E., and Brune, P. D. 1997. Effect of crop pruning on Sclerotinia blight of peanut. Plant Dis. 81:990-995.

4. Bartlett, D. W., Clough, J. M., Godwin, J. R., Hall, A. A., Hamer, M., and Parr-Dobrzanski, B. 2002. Review the strobilurin fungicides. Pest Manage. Sci. 58:649-662.

5. Beute, M. K., and Rodriguez-Kabana, R. 1979. Effect of wetting and the presence of peanut tissues on germination of sclerotia of Sclerotium rolfsii produced in soil. Phytopathology 69:869-872.

6. Branch, W. D. 1996. Registration of 'Georgia Green' peanut. Crop Sci. 36:806.

7. Branch, W. D., and Brenneman, T. B. 1996. Pod yield and stem rot evaluation of peanut cultivars treated with tebuconazole. Agron. J. 88:933-936.

8. Brenneman, T. B., and Murphy, A. P. 1991. Activity of tebuconazole on Cercosporidium personatum, a foliar pathogen of peanut. Plant Dis. 75:699-703.

9. Brenneman, T. B., Murphy, A. P., and Csinos, A. S. 1991. Activity of tebuconazole on Sclerotium rolfsii and Rhizoctonia solani, two soilborne pathogens of peanut. Plant Dis. 75:744747.

10. Butzler, T. M., Bailey, J., and Beute, M. K. 1998. Integrated management of Sclerotinia blight in peanut: utilizing canopy morphology, mechanical pruning, and fungicide timing. Plant Dis. 82:1312-1318.

11. Chiteka, Z. A., Gorbet, D. W., Shokes, F. M., Kucharek, T. A., and Knauft, D. A. 1988. Components of resistance to late leaf spots in peanut. I. Levels of variability-implications for selection. Peanut Sci. 15:25-30.

12. Coley-Smith, J. R., and Cooke, R. C. 1971. Survival and germination of fungal sclerotia. Annu. Rev. Phytopathol. 9:65-92.

13. Coyne, D. P., Stedman, J. R., and Anderson, F. N. 1974. Effect of modified architecture of 
great northern dry bean varieties (Phaseolus vulgaris) on white mold severity and components of yield. Plant Dis. Rep. 58:379-382.

14. Culbreath, A. K., Brenneman, T. B., Bondari, K., Reynolds, K. L., and McLean, H. S. 1995. Late leaf spot, southern stem rot, and peanut yield responses to rates of cyproconazole and chlorothalonil applied alone and in combination. Plant Dis. 79:1121-1125.

15. Culbreath, A. K., Brenneman, T. B., and Kemerait, R. C., Jr. 2001. Applications of mixture of copper fungicides and chlorothalonil for management of peanut leaf spots diseases. Plant Health Progress doi:10.1094/PHP-20011116-01-RS.

16. Culbreath, A. K., Brenneman, T. B., and Kemerait, R. C., Jr. 2002. Management of early leaf spot of peanut with pyraclostrobin as affected by rate and spray interval. Plant Health Progress doi:10.1094/PHP-2002-101801-RS.

17. Culbreath, A. K., Brenneman, T. B., Kemerait, R. C., Jr., and Stevenson, K. L. 2005. Relative performance of tebuconazole and chlorothalonil for control of peanut leaf spot from 1994 through 2004. (Abstr.) Proc. Am. Peanut Res. Educ. Soc. 37:54-55.

18. Deshpande, R. Y., Hubbard, K. G., Coyne, D. P. Steadman, J. R., and Parkhurst, A. M. 1995. Estimating leaf wetness in dry bean canopies as a prerequisite to evaluating white mold disease. Agron. J. 87:613-619.

19. Grichar, W. J. 1995. Management of stem rot of peanuts (Arachis hypogaea) caused by Sclerotium rolfsii with fungicides. Crop Prot. 14:111-115.

20. Hagan, A. K., Rivas-Davila, M. E., Bowen, K. L., and Wells, L. 2004. Comparison of fungicide programs for the control of early leaf spot and southern stem rot on selected peanut cultivars. Peanut Sci. 31:22-27.

21. Hustert, K., Feicht, E. A., and Kettrup, A. 2002. Photodegradation of azoxystrobin and kresoxim-methyl under simulated environmental conditions. Fresenius Environ. Bull. 11:322-325.

22. Kemerait, R. 2005. Georgia plant disease loss estimates. Coop. Ext. Serv. Bull. 41-08, University of Georgia, Athens.

23. Kemerait, R. 2006. Georgia plant disease loss estimates. Coop. Ext. Serv. Bull. 41-09, University of Georgia, Athens.

24. Kemerait, R. 2007. Georgia plant disease loss estimates. Coop. Ext. Serv. Bull. 41-10, University of Georgia, Athens.

25. Kemerait, B., Brenneman, T., and Culbreath, A. 2006. Peanut disease control. Pages 126127 in: Georgia Pest Management Handbook. P. Guillebeau, ed. Special Bull. 28, University of Georgia, Athens

26. Linderman, R. G., and Gilbert, R. G. 1973. Behavior of Sclerotium rolfsii produced in soil or in culture regarding germination stimulation by volatiles, fungistasis, and sodium hypochlorite treatment. Phytopathology 63:500-504.

27. Mazellier, P., Leroy, E., and Legube, B. 2002. Photochemical behavior of the fungicide carbendazim in dilute aqueous solution. J. Photochem. Photobiol. A: Chem. 153:221-227.

28. McDonald, M. R., Vander Kooi, K. D., and Westerveld, S. M. 2008. Effect of foliar trimming and fungicides on apothecial number of Sclerotinia sclerotiorum, leaf blight severity, yield, and canopy microclimate in carrot. Plant Dis. 92:132-136.

29. McRoberts, N., Hughes, G., and Madden, L. V. 2003. The theoretical basis and practical application of relationships between different disease intensity measurements in plants. Ann. Appl. Biol. 142:191-211.

30. Nag, S. K., and Dureja, P. 1997. Photodegradation of azole fungicide triadimefon. J. Agric. Food Chem. 45:294-298.

31. Punja, Z. K. 1985. The biology, ecology, and control of Sclerotium rolfsii. Annu. Rev. Phytopathol. 23:97-127.

32. Punja, Z. K., and Rahe, J. E. 1992. Sclerotium. Pages 166-170 in: Methods for Research on Soilborne Phytopathogenic Fungi. L. L. Singleton, J. D. Mihail, and C. M. Rush, eds. American Phytopathological Society Press, St. Paul, MN.

33. Rideout, S. L., Brenneman, T. B., Culbreath, A. K., and Langston, D. B., Jr. 2008. Evaluation of weather-based spray advisories for improved control of peanut stem rot. Plant Dis. 92:392-400.

34. Santos, R. B., and Sutton, B. G. 1983. Effect of defoliation on reproductive development of the peanut. Aust. J. Agric. Res. 34:527-535.

35. Sconyers, L. E., Brenneman, T. B., Stevenson, K. L., and Mullinix, B. G. 2005. Effects of plant spacing, inoculation date, and peanut cultivar on epidemics of peanut stem rot and tomato spotted wilt. Plant Dis. 89:969-974.

36. Shokes, F. M., and Culbreath, A. K. 1997.
Early and late leaf spots. Pages 17-20 in Compendium of Peanut Diseases, 2nd ed. N. Kokalis-Burelle, D. M. Poter, R. RodriguezKabana, D. H. Smith, and P. Subrahmanyam, eds. American Phytopathological Society Press, St. Paul, MN.

37. Stevenson, K. L., and Culbreath, A. K. 2006. Evidence for reduced sensitivity to tebuconazole in leaf spot pathogens. (Abstr.) Proc. Am Peanut Res. Educ. Soc. 38:62.

38. Stevenson, K. L., Padgett, G. B., and Culbreath, A. K. 1999. Sensitivity of early and late peanut leaf spot pathogens to DMI fungicides. (Abstr.) Proc. Am. Peanut Res. Educ. Soc. $31: 23$.

39. Subrahmanyam, P., McDonald, D., Walliyar, F., Raddy, L. J., Nigam, S. N., Gibbons, R. W. Rammanatha, R. V., Singh, A. K., Pande, S. Reddy, P. M., and Subba Rao, P. V. 1995. Screening methods and sources of resistance to rust and late leaf spot of groundnut. Bull. 47:120. ICRISAT, Patancheru, India

40. Turner, J. W. 1982. Effect of defoliation on yield of peanut (Arachis hypogaea). Queensl. J. Agric. Anim. Sci. 39:1983-185.

41. Ueda, M., Nakamura, Y., and Okada, M. 2007. Endogenous factors involved in the regulation of movement and "memory" in plants. Pure Appl. Chem. 79:519-527.

42. Vialaton, D., and Richard, C. 2002. Phototransformation of aromatic pollutants in solar light: photolysis versus photosensitized reactions under natural water conditions. Aquat. Sci. 64:207-215.

43. Weiss, A., Hipps, L. E., Blad, B. L., and Steadman, J. R. 1980. Comparison of within canopy microclimate and white mold disease (Sclerotinia sclerotiorum) development in dry edible beans as influenced by canopy structure and irrigation. Agric. Meteorol. 22:1121.

44. Williams, E. J., and Drexler, J. S. 1981. A nondestructive method for determining peanut pod maturity. Peanut Sci. 8:134-141.

45. Woodward, J. E. 2006. Optimizing efficacy and economic benefits of fungicides for peanut disease control via pre-plant analysis of disease risk and irrigation timing. Ph.D. dissertation, University of Georgia, Athens.

46. Woodward, J. E., and Brenneman, T. B. 2008 Development of an inoculation method for quantifying fungicide residues on peanut foliage. Peanut Sci. 35:25-31 